\title{
Abuse of psychiatry: analysis of the guilt of medical personnel
}

\author{
Semyon F Gluzman Kiev, USSR
}

Based on the generally accepted definition, we correctly term the utilisation of psychiatry for the punishment of political dissidents as torture. The widely known sources, in particular written and published memoirs of victims of psychiatric arbitrariness, report in detail on those physical and moral sufferings to which victims of psychiatric arbitrariness were subjected within the walls of special psychiatric hospitals in my country.

My foreign colleagues as well as journalists fixed their attention mainly on the names of torture (in other words, on the conditions of maintenance and 'treatment') and on the persons who were the direct utilisers of torture: doctors, middle- medical personnel and orderlies, these last being from among criminal offenders.

Thorough and extensive research of this problem shows there were significantly more direct and indirect participants among the abusers.

A law-abiding civilised government determines guilt in the form of action or inaction. In other words, the consciousness (memory) of this or that person of the inadmissability (illegality) of his conduct and the results associated with that.

The totalitarian state is a closed, harsh social system, which by the strength of its very nature avoids any kind of serious social innovation. In totalitarian societies, there is little application of law; in such societies much is decided with the help of politics. Throughout, politicised totalitarian systems subordinate law to momentary administrative circumstances. Soviet psychiatry, as a social institution formed and functioning in totalitarian society, cannot be nontotalitarian. Because it is all but a sub-system, its characteristics are determined from the very beginning. Totalitarian thought is particular in its conviction that the world is simple and completely known, that absolute classification of physical objects as well as human thought and behaviour are possible. For the ordinary doctor-psychiatrist, totalitarian education implants the illusion that he/she possesses absolute knowledge. This dangerous illusion gives him the certainty that his working psychiatric conception applies to all cases in his practice without exception, that the worlds of insanity and sanity are clearly delineated and stable, and that in human consciousness and behaviour there does not exist, and cannot exist, temporary and national conditions.

Disagreement with and resistance to authority are integral to the human consciousness. They form one of the guarantees of a dynamic balance within democratic social systems. However, an educated, uniform view of the world inescapably leads to a situation where any manifestation of resistance must pass through the totalitarian consciousness with its thick bars of conceptual psychiatric morals.

Why does the totalitarian state, possessing absolute power on its territory, resort in a number of cases to camouflage, to psychiatric repression of dissidents? The answer is simple: complete totalitarianism almost never resorts to psychiatric camouflage. Such, in its ideals, was the totalitarianism of the Stalin epoch. The totalitarianism of the Brezhnev epoch (I define this as 'implanted totalitarianism') did not possess such absoluteness in power and therefore psychiatric repression was utilised in the capacity of frightening 'arms from above' which is much more terrible than normal prisons and camps.

From the totalitarian state's legislative perspective, dissidence is a crime. From the perspective of the psychiatrist educated in totalitarian society, moral, religious or political dissidence is a manifestation of mental illness. The doctor living and working in a totalitarian society is doomed to be an undisclosed wheel, whatever his qualifications, personal qualities and convictions might be. The alternative is death, exile or prison. Sooner or later, the doctor makes a choice, most often unconsciously. I am not sure that the precise juridical personification of Evil is possible in all cases of the utilisation of psychiatry for the repression of dissidents. Clearly and argumentatively it is possible to personify the chief accused in the court of history as the totalitarian system, in which the utilisers of psychiatric repression could be, at the mercy of fate, not Lunts and Morozov but, for example, Gluzman and Koryagin. At the same time, in the tortures enabled by the all-possible, world-embracing psychiatric explanations, real people took part. Both actively and passively.

In the first place, there were the leaders of the government, they provided the ideological apparatus. Then secondly, there were those who served in the 
political police (KGB), directly executing the will of the leaders of the country; these were the arresters, determining the further fate of the arrested, putting down the 'social order' to the 'expert-psychiatrist'.

Thirdly, come the psychiatrists: from totally qualified expert-professors, consciously and cynically finding the expression of 'madness' in their completely healthy fellow-citizens, to utilisers of psychiatric repression in special psychiatric hospitals. These latter were, as a rule, people of the lowest professionalmedical qualifications.

There is still another group of people who are guilty of the fact that psychologically healthy people in various countries underwent torture within the walls of psychiatric institutions. Their guilt is inaction. These people are international bureaucrats.

I remind the reader that, in 1975, 'governing principles' were adopted for doctors concerning torture and other brutal inhuman or degrading kinds of treatment in connection with arrest and imprisonment and were included in the Tokyo Declaration of the World Medical Association.

In 1983 the international journal Chronicle WHO published 'The principles of medical ethics with regard to the role of those working in the health field, especially doctors, in defence of prisoners from torture and other brutal, inhuman or degrading kind of attention and punishment'. The general assembly of the United Nations, adopting the principles of resolution 37/194, summoned all governments to 'secure the broadest dissemination of the texts of these documents in the official language of the given state, in part among the associations of medical and paramedical personnel and institutions whose function is to detain or imprison'.

In 1975 and 1983 it became known to the world that a number of governments (including the USSR, Romania and Cuba) used both archaic and modern methods of psychiatric treatment in the form of torture, purposely causing people enormous pain, physical and moral suffering. Also, it was known there were witnesses .... .

Neither the director general of the World Health Organisation nor the director of the department for the protection of mental health of the World Health Organisation (WHO) manifested professional or human interest in this problem. So during several contacts with the Soviet side, in Moscow, neither Dr Maler nor Dr Sartorius asked: 'How does the Ministry of Health of the USSR inform the medical and paramedical personnel of special psychiatric hospitals of the Ministry of Internal Affairs on the UN Principles of Medical Ethics? Is the Ministry of Health fulfilling its international objectives?'

Unfortunately, the UN Principles of Medical Ethics were not broadly disseminated in the USSR. Neither in the system of the Ministry of Health nor in the system of the Ministry of Internal Affairs were they placed before the medical personnel for acquaintance. Torture with sulfazine, atropine, insulin and massive doses of neuroleptics continued. So did the beatings, starvation and punishment for finding a piece of a slatepencil and a scrap of paper ... on a 'patient'.

The Ministry of Health of the USSR, having in fact allowed the torture of its fellow-citizens within the walls of special psychiatric hospitals is silent today about the existence of the UN Principles of Medical Ethics... .

It is obvious that the signing by the USSR of the conventions against torture and other brutal, inhuman or degrading kinds of attention or punishment of December 10, 1985 is especially declarative. The known stipulations in the ratification act of the Soviet side witness to this. In such a situation no one can guarantee that psychiatric terror in my country will not have a place in the present and future.

For creation of solid guarantees for the future, at the very least, the following is necessary:

1. Creation by Soviet legislation of an effectively working psychiatric law, upholding legal procedures and legal guarantees;

2. Ratification by Soviet legislation of the complete text of the Convention against Torture;

3. Broad dissemination of the UN Principles of Medical Ethics among medical and para-medical personnel of the system of the Ministry of Health and the system of the Ministry of Internal Affairs of the USSR, and

4. The fulfilment by the international bureaucrats of the World Health Organisation of their functional, professional and human duty.

Semyon Gluzman, $M D$, is a psychiatrist in Kiev, USSR. 